\title{
Maps of Ephemeral Empires: The ICJ and the Macedonian Name Dispute
}

Francesco Messineo*

\section{Lost empires, modern maps and name disputes}

In Rome, on one side of the Via dei Fori Imperiali (the road connecting the Coliseum and the Piazza Venezia cutting through the archaeological excavations of the Imperial Fora) one can find some maps displaying the successive phases of expansion of the Roman Empire. These were carved in stone during Mussolini's dictatorship: 'The Empire at the Age of Trajan' is the crucial one, as it shows Rome at its maximum territorial expansion in the $1^{\text {st }}$ and $2^{\text {nd }}$ century CE. ${ }^{1}$ For its 1933 audience, the message was clear: the Italians were now reclaiming that legacy and heritage, as if $476 \mathrm{CE}$ had never happened. ${ }^{2}$

\footnotetext{
Lecturer in Law, Kent Law School, Canterbury. A previous draft of this note was presented at the workshop on "Judicial Conversations: the Role of Judiciaries in Resolving International Conflicts" hosted by Law and Conflict at Durham (LCD) and by the Centre for Criminal Law and Criminal Justice on 26 and 27 April 2012 at University College Durham. Many thanks to the organizers and all the participants for their comments and to the Modern Law Review for co-sponsoring the event. The author is also indebted to Federica Cittadino, Alessandra Iacono, Viktorija Jakimovska, Irena Micajkova, Marko Milanović, Ioanna Pervou, Judge Bruno Simma, Rumiana Yotova and Demian Zucal for their help and for their kind comments. The usual disclaimers apply.

1 A picture thereof may be seen at <http://commons.wikimedia.org/wiki/File:Roma-Via_ dei_fori_imperiali.jpg > (by Dan Kamminga) [last accessed 22 April 2012]. Interestingly for our present purposes, the map includes 'Macedonia' as a large area from Albania to the Aegean Sea, in a manner which seems to include all of Northern Greece, while Acaia (Achaea) is the name given to the Southern part of Greece, but there are no borders between provinces of the pax romana.

2 On the legacy of 'imperial Rome' as a crucial element in the construction of Fascist national identity, see e.g. P. Costa, Civitas: Storia della cittadinanza in Europa-vol. 4, L'età dei totalitarismi e della democrazia (Laterza, 2008), at 283 (esp. note 196 and accompanying text).
} 
For a state which was only about 70 years old in 1933, this was a ludicrous claim - and yet much pain was caused in many places, including the Balkans, by the disastrous nationalist ideology underpinning that assertion. How that story ended is an apt reminder that arguments based on the geographical boundaries of some past historical entity are seldom a good idea, whichever side they come from.

Ancient maps of lost empires feature prominently in the on-going 'denominational conflict' between the Hellenic Republic ('Greece' hereinafter) and the country referred to within the United Nations and other international organizations as 'the former Yugoslav Republic of Macedonia' ('Makedonija' hereinafter). ${ }^{3}$ Ever since the independence of Makedonija from Yugoslavia more than twenty years ago, Greece has continuously objected to the name 'Republic

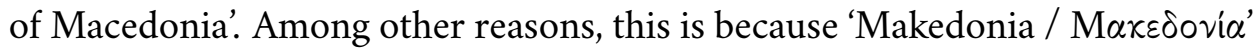
has been the name of a large territorial unit of Northern Greece since 1914. ${ }^{4}$ The difference is still unresolved, but a discrete issue connected to it was adjudicated upon by the International Court of Justice on 5 December 2011. The Court held that Greece had breached one of its obligations under the 1995 bilateral Interim Accord by objecting to the admission of Makedonija to NATO in the run up to the Bucharest Summit of 2008. ${ }^{5}$

This article reviews the ICJ judgment and discusses its impact on the name dispute. The aim here is not to provide a detailed analysis of all the many interesting legal issues raised by the case. ${ }^{6}$ Rather, I intend to show that, despite

3 See SC Res. 817, 7 April 1993 and 1995 Interim Accord, 1891 UNTS 3. The present author will use the transliteration of the constitutional name of the Republika Makedonija (Република Македонија) without any translation in order to distinguish it from the Northern Greek region of Makedonia / M $\alpha x \varepsilon \delta o v i \alpha$ (and avoid the equally contested acronym FYROM). This should be seen as a purely pragmatic compromise, not an expression of a view (let alone a proposal) on the final solution of the 'name issue' discussed here.

4 "Greece was the first to use the term 'Macedonia', as early as 1914, to designate a large administrative unit of its new territories", as the Agent of Greece put it before the Court: Translation of Verbatim Record of Oral Proceedings, CR 2011/8, 24 March 2011 (3 pm), available at <http://www.icj-cij.org/docket/files/142/16378.pdf> [last accessed 22 April 2012], at 8 . What the Agent meant is that, as between Greece and Makedonija, Greece was the first to use the name-the term 'Macedonia' had obviously been used before.

5 Application of the Interim Accord of 13 September 1995 (the former Yugoslav Republic of Macedonia $v$ Greece), Judgment (not yet published), 5 December 2011, available at $<\mathrm{http}$ ://www.icjcij.org/docket/files/142/16827.pdf> [last accessed 22 April 2012].

${ }^{6}$ In that regard see e.g. A. Tzanakopoulos, 'Legality of Veto to NATO Accession: Comment on the ICJ's Decision in the Dispute between fYR Macedonia and Greece', EJIL: Talk!, 7 December 2011, available at <http://www.ejiltalk.org/legality-of-veto-to-nato-accession> [last accessed 22 April 2012]. 
the formal separation between the name dispute and the object of the legal dispute before the ICJ, the Court's judgment can in fact be construed as an intervention in the name dispute. As such, it was perhaps at the limits of the Court's jurisdiction under the terms of Article 21(2) of the Interim Accord. However, irrespective of the jurisdictional question, and notwithstanding the dismissive remarks of NATO officials as to its immediate practical impact, ${ }^{7}$ the judgment might perform a useful function towards the long-awaited final resolution of the name dispute, because it clarified some of the respective legal positions of the parties.

Before proceeding any further, one might wonder why the name question is so important. On one level, this is a dispute about ownership of cultural heritage: who has the best claim to be the 'real inheritor' of 'historical' Macedonia, the land of Philip II and Alexander the Great, which at some point became an empire spanning from Egypt to India? On both sides, the arguments are often the modern-day equivalent of those carved stone maps of 1933. Yet, even the most biased historical accounts recognize at least some shared heritage: at some point in history, there was indeed a geographical entity called 'Macedonia' covering both the current Greek region of Makedonia/M $\alpha \times \varepsilon \delta \circ v i \alpha$ and (at least parts of) Makedonija and other neighbouring countries. ${ }^{8}$ However, the boundaries of this 'historic' Macedonia (and its exclusively Hellenic characterization) are still a matter of dispute, with both parties to the conflict often making claims as to the 'percentage' of that ancient land that 'belongs' to them. ${ }^{9}$ This is not a trivial disagreement: for both Makedonija and Greece, it runs deep into matters of national identity. ${ }^{10}$ It is thus not surprising that maps included in primary school textbooks featured prominently in the pleadings of the parties before the ICJ, ${ }^{11}$ alongside

7 See NATO's Secretary General statement, 5 December 2011, available at <http://www.nato.int/cps/en/SID-50672CA8-1A1DD013/natolive/news_81678.htm> [last accessed 22 April 2012].

${ }^{8}$ See e.g. G. C. Papavizas, Claiming Macedonia: The Struggle for the Heritage, Territory and Name of the Historic Hellenic Land (McFarland, 2006), at 221 (the author, who seeks to discuss the history of "the Macedonian question from a Greek perspective", a contrario concedes that "part" of Makedonija "belonged to historic Macedonia").

9 See e.g. supra, note 5 , at 8 .

${ }^{10}$ It also raises questions as to the exploitation of these issues by the educational and political elites of both countries, now and at some very complex turning points during the Twentieth Century.

${ }^{11}$ In the Counter-Memorial of Greece there are no less than 56 references to textbooks in use in the elementary schools of the Republika Makedonija, which Greece deems in breach of Makedonija's obligations under the Interim Accord on various grounds. See Counter-Memorial 
gastronomic detours on the 'real' ownership of moussaka. ${ }^{12}$

In terms of cultural heritage, the question is obviously not for international lawyers to solve-archaeologists, historians and anthropologists are much better placed to reach some conclusions (or at least explain why a conclusion cannot be reached). ${ }^{13}$ Yet, very practical concerns underlie the cultural aspects of the dispute. ${ }^{14}$ In Greek eyes, the name 'Republic of Macedonia' is unacceptable because it is an "historical injustice" 15 which may imply "irredentist" territorial claims over its Northern territorial unit named Makedonia/M $\alpha x \varepsilon \delta \circ v i \alpha-$ especially in light of the complex relationship between Tito's Yugoslavia and Greece (a situation not helped by certain declarations made by authorities and politicians in Makedonija in the early 1990s). ${ }^{16}$ Initially, Greece opposed any use of the term 'Macedonia' in the name of its neighbour, but its current position is that a compound name distinguishing it from Greek Makedonia/M $\alpha \times \varepsilon \delta o v i \alpha$ would be acceptable. ${ }^{17}$ On the other hand, in Makedonija's eyes this is an "entirely absurd" dispute. ${ }^{18}$ Makedonija insists that it has a right to choose its own name; that there are no territorial claims implied in calling itself 'Macedonia' (as recognized inter alia by the Badinter Commission in 1992): ${ }^{19}$ and that both

of Greece, 19 January 2010, available at <http://www.icj-cij.org/docket/files/142/16356.pdf> [last accessed 22 April 2012], passim. Further references may be found both in the Rejoinder and in the oral proceedings.

${ }^{12}$ Verbatim Record of Oral Proceedings, CR 2011/5, 21 March 2011 (3 pm), available at <http://www.icj-cij.org/docket/files/142/16362.pdf> [last accessed 22 April 2012], at 34. This was perhaps a more serious issue than counsel for Makedonija characterized it to be, if one is reminded, for instance, of analogous disputes in the Middle East about the 'ownership' of falafel; anthropologists rightly insist that food and identity are inextricably linked, especially in post-independence contexts: see e.g. M. K. Janeja, Transactions in Taste (Routledge, 2010).

${ }^{13}$ Some of the cultural terms of the dispute are well summarized by J. Romm, "Who was in Tomb II?', London Review of Books, vol. 33, issue 19, 6 October 2011, at 27-28, who clarifies that those scholars are obviously not exempt from bias either. For an anthropological perspective, see J.K. Cowan, Macedonia: The Politics of Identity and Difference (Pluto Press, 2000). On the possible international legal implications of the cultural dispute, see L. Reimer, 'Macedonia: Cultural Right or Cultural Appropriation?', (1995) 53 U. Toronto Fac. L. Rev. 359.

${ }^{14}$ The political dimension of the dispute and Makedonija's international relations from independence up to the early 2000s are well described by the former head of the UN Preventive Deployment Force in H.J. Sokalski, An Ounce of Prevention: Macedonia and the UN Experience in Preventive Diplomacy (US Institute of Peace Press, 2003).

${ }^{15}$ Counter-Memorial of Greece, supra, note 11, at 15.

${ }^{16}$ See ibid., paras. 2.9-2.13.

${ }^{17}$ Ibid., para. 2.34.

${ }^{18}$ See Application instituting proceedings, available at <http://www.icj-cij.org/docket/files /142/14879.pdf> [last accessed 22 April 2012], at 166.

${ }^{19}$ Arbitration Commission of the Conference on Yugoslavia, 'Opinion No. 6 on the Recognition 
the constitution and the flag of the country have been amended precisely to assuage such fears. ${ }^{20}$ The internal situation in Makedonija is also complicated by its relationship with its other neighbours Bulgaria, Albania and, to a lesser extent, Serbia. Claiming the 'Macedonian' heritage of a 'Macedonian' nation is an essential element in that picture. ${ }^{21}$

\section{The obligation to negotiate and its deflection}

Despite this overall complexity, mutual relations between Greece and Makedonija are much better now than they were in the early 1990s, when the conflict threatened to become much more serious. Greece initially refused to recognize Makedonija as a state and was quite successful in its diplomatic efforts to make sure that other European countries delayed their recognition despite the favourable Badinter Commission's report. ${ }^{22}$ In 1993, Makedonija succeeded in gaining admission to the United Nations, but Greek opposition led to the terms of resolution 817 (1993), according to which the country would be "provisionally referred to for all purposes within the United Nations as 'the former Yugoslav Republic of Macedonia' pending settlement of the difference that [had] arisen over the name of the State". ${ }^{23}$ Negotiations continued. The Interim Accord of 1995 accomplished the objective of normalizing day-to-day relations with Greece, although the parties could only agree in writing to refer to each other as 'The Party of the First Part' (Greece) and 'The Party of the Second Part' (Makedonija). They assumed the obligation to continue the negotiations, although explicitly reserving their positions. This was meant to 'cool down' the conflict. According to Article 5:

of the Socialist Republic of Macedonia by the European Community and Its Member States', 11 January 1992, Annex III to supra, note 18, at 46.

${ }^{20}$ The first flag of Makedonija included, with a different background colour, the Star of Vergina,

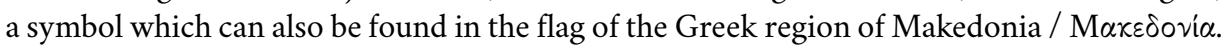
The significance of that is explained by Romm, supra, note 13. Makedonija subsequently renounced all official use of the Star in Article 7 of the Interim Accord (supra, note 3).

${ }^{21}$ See generally J. Engström, 'The Power of Perception: The Impact of the Macedonian Question on Inter-ethnic Relations in the Republic of Macedonia', (2002) 1 Global Review of Ethnopolitics 3 ("At the heart of the Macedonian Question are conflicting perceptions and dogmas of the ethnic origin of the Macedonian nation, and the specific question of whether a distinct Macedonian nation actually exists.").

${ }^{22}$ See C. Warbrick, 'Recognition of states: Part 2', (1993) 42 ICLQ 433, at 437-8.

${ }^{23}$ Supra, note 3 . 
1. The Parties agree to continue negotiations under the auspices of the Secretary-General of the United Nations pursuant to Security Council resolution 845 (1993) with a view to reaching agreement on the difference described in that resolution and in Security Council resolution 817 (1993)

2. Recognizing the difference between them with respect to the name of the Party of the Second Part, each Party reserves all of its rights consistent with the specific obligations undertaken in this Interim Accord. The Parties shall co-operate with a view to facilitating their mutual relations notwithstanding their respective positions as to the name of the Party of the Second Part. In this context, the Parties shall take practical measures, including dealing with the matter of documents, to carry out normal trade and commerce between them in a manner consistent with their respective positions in regard to the name of the Party of the Second Part. The Parties shall take practical measures so that the difference about the name of the Party of the Second Part will not obstruct or interfere with normal trade and commerce between the Party of the Second Part and third parties. ${ }^{24}$

In the Accord, Greece finally recognized Makedonija as a state and agreed to cooperate with it in various ways. Crucially, Greece also undertook the obligation not to object to Makedonija's admission to international organizations, so long as the provisional name would be used. Article 11(1), which was to become central to the dispute before the ICJ, provided:

Upon entry into force of this Interim Accord, the Party of the First Part agrees not to object to the application by or the membership of the Party of the Second Part in international, multilateral and regional organizations and institutions of which the Party of the First Part is a member; however, the Party of the First Part reserves the right to object to any membership referred to above if and to the extent the Party of the Second Part is to be referred to in such organization or institution differently than in paragraph 2 of United Nations Security Council resolution 817 (1993). ${ }^{25}$

\footnotetext{
${ }^{24}$ Interim Accord, supra, note 3.

${ }^{25} \mathrm{Ibid}$.
} 
In exchange, Makedonija modified its flag and accepted other important "confidence-building" obligations. ${ }^{26}$

This was perhaps not such a good deal for Makedonija-albeit a necessary one at the time. In its successful struggle to seek a swift integration in the international community, Makedonija chose to pay a considerable price in terms of its legal rights. Without the Interim Agreement of 1995, the basic position in international law as to the name dispute would have been clearly in favour of Makedonija. Countries have a sovereign right to call themselves by a name of their choosing. This may be construed either a simple corollary of sovereignty, or as part of basic self-determination principles. In the case of Makedonija, this is all the more so given that the name 'Macedonia' was already in use before its 1991 independence as the name of the corresponding Yugoslavian territorial unit (the 'Socialist Republic of Macedonia'). The concept of uti possidetis iuris is meant to avoid unnecessary 'fratricidal struggles' on the position of borders once independence is gained through self-determination. ${ }^{27}$ It may perhaps be extended by analogy to the question of the name of a state-the point would be that Makedonija already had a right to call itself Macedonia, because that was its name, and that right persisted, insofar as it already existed, even after gaining independence and dropping the word 'Socialist' therefrom. With the exception of some biased voices to the contrary, ${ }^{28}$ the best academic opinion at the time supported Makedonija's right to call itself the 'Republic of Macedonia.. ${ }^{29}$ In the case before the ICJ examined here, even the Respondent, Greece, accepted that it would in the abstract be Makedonija's 'prerogative' to call itself whatever it wants. As Professor Crawford put it:

The key point about Article 5 is that it entails an agreement by the Applicant not to exercise its prerogative of determining its name

\footnotetext{
${ }^{26}$ See supra, note 20.

${ }^{27}$ See Frontier Dispute (Burkina Faso/Republic of Mali), Judgment, ICJ Reports 1986, p. 554, at 565, para. 20.

${ }^{28}$ See e.g. M.D. Poulakidas, 'Macedonia: Far More Than a Name to Greece', (1994-1995) 18 Hastings Int'l \& Comp. L. Rev. 397.

${ }^{29}$ See e.g. M.C.R. Craven, 'What's in a Name? The Former Yugoslav Republic of Macedonia and Issues of Statehood', (1995) 16 Aust. YBIL 199, at 234-5. Contra, see I. Bantekas, 'The Authority of States to Use Names in International Law and the Macedonian Affair: Unilateral Entitlements, Historic Title, and Trademark Analogies', (2009) 22 LJIL 563 (the author advocates the relevance of the maxim prior in tempore, potior in iure, and draws an analogy with the law on trademarks, to reach the conclusion that Makedonija is not entitled to the use of the term 'Macedonia').
} 
for itself. [...] The only rule of general international law is that it is for each State to determine its own name, just as it is to determine its own flag, or its national anthem. The national song of Poland, I might say, begins with the words 'O, Lithuania', but no one has ever complained! ${ }^{30}$

Indeed, in Greece's view, the Interim Accord changed everything, as it imposed on Makedonija an obligation to negotiate with another country its own name. Or did it?

A cunning deflection strategy soon emerged in Makedonija. First, the country would seek to be recognized with its 'constitutional' name by as many other states as possible. Second, authorities would insist on always using only the name 'Republic of Macedonia' in every international setting-even when referred to by other states and international organizations as the former Yugoslav Republic of Macedonia'. The consistency in this regard was particularly irritating to Greece, whose counsel resorted to describing some of Makedonija's acts as "childish". ${ }^{31}$ Third, the negotiations with Greece mandated by Article 5(1) of the Interim Accord were approached on the basis that the international use of the name 'Republic of Macedonia' was not negotiable: Makedonija was only prepared to discuss a suitable name to be employed in bilateral relations between Makedonija and Greece. This position, known as the 'dual formula', was seen by Greece as an unlawful strategy aimed at avoiding meaningful negotiations on the name issue despite the precise commitment to engage therein under Article 5(1) of the Interim Accord. ${ }^{32}$ In summary, the parties could no longer even agree on what their disagreement exactly consisted in. Negotiations all but froze, while recognition of the name 'Republic of Macedonia' by third countries was on the rise.

Irrespective of its legality or good faith, this was an excellent strategy from Makedonija's perspective. Makedonija gained admittance to many international organizations, ${ }^{33}$ and many states recognized it under its constitutional name. All was well until it all worked too well. In the mid-2000s, the United

\footnotetext{
${ }^{30}$ Verbatim Record of Oral Proceedings, CR 2011/12, 30 March 2011 (3 pm), available at <http://www.icj-cij.org/docket/files/142/16390.pdf> [last accessed 22 April 2012], at 32.

${ }^{31}$ Rejoinder of Greece, 27 October 2010, available at <http://www.icj-cij.org/docket/files/142/ 16360.pdf $>$ [last accessed 22 April 2012], para. 7.32.

${ }^{32}$ See the 2008 remarks by Makedonija's President in his Parliament reported in the Greek Counter-Memorial, supra, note 11, para. 3.47, and the Greek position thereupon, paras. 3.48, 4.9, and 8.39.

${ }^{33}$ Judgment, supra, note 5, para. 22.
} 
States of America and a series of other powerful countries joined the ranks of those recognizing Makedonija's constitutional name. ${ }^{34}$ Understandably worried that it might be put before an irreversible series of faits accomplis, Greece hardened its position and made it clear to everyone in intergovernmental, diplomatic, and media circles that it intended to put some pressure back on Makedonija at the negotiation table by objecting to its admission to NATO, which was due to be decided upon at the Bucharest Summit of $2008 .^{35}$ Because of its consensus-based decision-making process, NATO ended up unanimously deciding not to extend an invitation to Makedonija until the name dispute was solved. ${ }^{36}$ Makedonija's reaction was to bring a case against Greece before the International Court of Justice (ICJ), lamenting a breach of Article 11(1) of the Accord.

\section{Greece's breach of Article 11(1)}

\subsection{The ostensibly simple case of Makedonija vs. the complex reply of Greece}

Against this background, the first thing to note about the judgment is that the Court was prevented from deciding the crucial underlying question-whether Makedonija had the right, under international law, to choose for itself the name 'Republic of Macedonia'. By virtue of Article 21(2) of the Interim Accord, the International Court of Justice could be seized of "any difference or dispute" arising between Greece and Makedonija concerning "the interpretation or implementation" of the Accord, except "the difference referred to in Article 5, paragraph 1", that is the "difference described in [Security Council] resolution [845 (1993)] and in Security Council resolution 817 (1993)". In other words, the Court had no jurisdiction over the "difference ... arisen over the name of the State" mentioned in resolution 817 (1993) and, according to Greece, neither had it as to the "remaining issues between them" mentioned in SC resolution 845 (1993).

Counsel for Makedonija was very successful in convincing the Court that the dispute before it had, strictly speaking, nothing to do with the name issue. Makedonija sought a declaration that Greece had breached its obligation under Article 11(1) not to object to Makedonija's membership of NATO. Greece had

\footnotetext{
${ }^{34}$ See Counter-Memorial of Greece, supra, note 11, para. 2.31.

${ }^{35}$ Judgment, supra, note 5, para. 21.

${ }^{36} \mathrm{Ibid}$.
} 
indeed objected, and it had not done so for the only reason it would have been allowed to do so under Article 11(1). It was, as Professor Sands put it before the Court, a "simple and narrow case of pacta sunt servanda": ${ }^{37}$ the Court did not need to enmesh itself with NATO's decisions or procedures, nor with the name dispute. Indeed, the Court was not asked to decide whether the Party of the Second Part should be called FYROM, Macedonia, or, for that matter, "the Republic of South Australia”. ${ }^{38}$ It was, on Makedonija's terms, an easy case. Not so for Greece.

For reasons that, with the benefit of hindsight, appear perhaps strategically unwise, Greece decided that it would not seek a separate judgment on preliminary objections, but that it would be prepared to join its arguments on the question of jurisdiction with those on the merits of the case. The resulting written and oral proceedings by Greece are very complex. In its most simplified form, Greece's line of defence can be understood as a series of no less than nine hierarchical propositions, each subsidiary to all the preceding ones in the following order:

1. The Court lacked jurisdiction under Article 21(2) of the Interim Accord because the dispute was inextricably connected to the name issue which was reserved for settlement through negotiation between the parties.

2. Even if the Court found that the dispute could be understood separately from the name issue, the Court lacked jurisdiction because it was not Greece which had objected to Makedonija's admission to NATO: the relevant act was attributable to NATO, not Greece.

3. Even if the act was also attributable to Greece, NATO and/or its members would have had to be necessary parties to the dispute, and the Monetary Gold principle prevented the Court from exercising jurisdiction. ${ }^{39}$

4. Even if the Monetary Gold principle did not apply, the Court should refrain from exercising jurisdiction to protect its judicial function, as the decision would not be susceptible of any practical effect: the Court could not order NATO to admit Makedonija. ${ }^{40}$

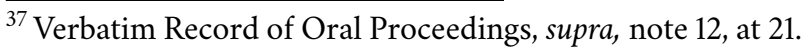

${ }^{38} \mathrm{Ibid}$, at 28.

${ }^{39}$ See Monetary Gold Removed from Rome in 1943 (Italy v France, United Kingdom of Great Britain and Northern Ireland and United States of America) (Preliminary Question), ICJ Reports 1954, p. 19.

${ }^{40}$ Note how this point potentially contradicts the assertion sub (1) that any decision on the issue would necessarily impact upon the name issue.
} 
5. The term "not to object" in Article 11(1) must be interpreted narrowly. The conduct of Greece should not be seen as an objection strictu sensu, but as an exercise of its duty of participation to the consensus-forming under NATO rules and procedures, which prevailed over the Interim Accord by virtue of Article 22 of the Accord.

6. Even if the conduct by Greece was deemed an objection, it was an objection permitted by the second clause of Article 11(1), because Makedonija would be referred to in NATO differently than "the former Yugoslav Republic of Macedonia": Makedonija itself would carry on its practice of calling itself "the Republic of Macedonia".

7. Even if Greek conduct was not permitted under either Article 22 or Article 11(1), it was permitted because Makedonija had breached many of its correlative obligations under the Accord, including eschewing meaningful negotiations through the "dual formula", and Greece was therefore entitled to invoke the exception of non-performance (exceptio non adimpleti contractus).

8. Even if the exceptio non adimpleti contractus were not a recognized rule under international law, the treaty obligation under Article 11(1) was suspended under the terms of the Vienna Convention of the Law of Treaties because Makedonija's breaches amounted to 'material breaches' and Greece relied on the "defence" mechanism of Article 65.

9. Failing all of the above, this was a case of legitimate countermeasures under the law of state responsibility.

The more persuasive the subsidiary arguments are, the more the arguments just heard by the Court on the points immediately before are undermined-even if they would not need to be as a matter of formal logic. As all uncles and aunts know, the arguments 'You are not my mum', followed by 'It was not me, uncle/auntie', followed by 'I actually did it because she hit me first' end up being all mutually exclusive even if one of them may be, on close analysis, correct. So Greece had to plead at the same time that the Court had no jurisdiction to hear the case, that there was no breach, and that the breach was excusable because Makedonija had also breached the rules, including some over which the Court supposedly had no jurisdiction. Another contradiction was that Greece pleaded that the judgment was not going to be capable of having any legal effect, while also arguing that it would actually adversely prejudice the negotiations-over 
which the Court had no jurisdiction-by creating irreversible legal effects. As Judge Simma put it in his separate opinion, counsel for Greece did an excellent job in very difficult circumstances-but "ad impossibilia nemo tenetur". ${ }^{41}$

\subsection{The Court's decision on jurisdiction}

The Court proceeded to tear Greece's arguments apart one by one. As to the argument that the Court's decision would fall under the exclusion in Article 21(2), the Court held the question of "which name should be agreed upon at the end of the negotiations between the Parties under the auspices of the United Nations" was the only one that the Court could not adjudicate upon, while the question of the violation of Article 11(1) was a separate one:

The fact that there is a relationship between the dispute submitted to the Court and the name difference does not suffice to remove that dispute from the Court's jurisdiction. [...] Only if the Court were called upon to resolve specifically the name difference, or to express any views on this particular matter, would the exception under Article 21, paragraph 2, come into play. This is not the situation facing the Court in the present case. ${ }^{42}$

As to Greece's argument that the relevant conduct under dispute was to be attributed to NATO rather than Greece, the Court agreed with Makedonija that this was a misrepresentation of the object of the dispute. It was Greek conduct in the run up to the Bucharest summit that came into consideration, not the Summit decision itself:

The Court notes that the Applicant is challenging the Respondent's conduct in the period prior to the taking of the decision at the end of the Bucharest Summit and not the decision itself. The issue before the Court is thus not whether NATO's decision may be attributed to the Respondent, but rather whether the Respondent violated the Interim Accord as a result of its own conduct. Nothing in the Application before the Court can be interpreted as requesting the Court to pronounce on whether

\footnotetext{
${ }^{41}$ Judge Simma, Separate Opinion, available at <http://www.icj-cij.org/docket/files/142/16829 .pdf $>$ [last accessed 22 April 2012], para. 3. Some self-contradiction by Greece was also hinted at in the Court's judgment, supra, note 5, para. 107.

${ }^{42}$ Judgment, supra, note 5, para. 37.
} 


\begin{abstract}
NATO acted legally in deferring the Applicant's invitation for membership in NATO. Therefore, the dispute does not concern, as contended by the Respondent, the conduct of NATO or the member States of NATO, but rather solely the conduct of the Respondent. ${ }^{43}$
\end{abstract}

This made the question of the Monetary Gold principle irrelevant, because Greece's “conduct [could] be assessed independently of NATO's decision, and the rights and obligations of NATO and its member States other than Greece [did] not form the subject-matter of the decision of the Court". ${ }^{4}$

Furthermore, the Court was not persuaded that its judgment would have no practical result:

While the Respondent is correct that a ruling from the Court could not modify NATO's decision in the Bucharest Summit or create any rights for the Applicant vis-à-vis NATO, such are not the requests of the Applicant. [...] The Applicant is not requesting the Court to reverse NATO's decision in the Bucharest Summit or to modify the conditions for membership in the Alliance. Therefore, the Respondent's argument that the Court's Judgment in the present case would not have any practical effect because the Court cannot reverse NATO's decision or change the conditions of admission to NATO is not persuasive. ${ }^{45}$

And finally, as to the argument that the judgment would intervene in political issues and the Court should thus refrain to adjudicate for judicial propriety, the Court predictably used its classic arguments on the nature of the dispute: there was a legal dispute between the parties over which the Court had jurisdiction, and there was no reason to refrain from exercising it just because there would be some political implications to that legal decision. ${ }^{46}$

\title{
3.3 The obligation 'not to object' to NATO membership
}

Once the Court established that it had jurisdiction, it went on to consider what the obligation 'not to object' to Makedonija's entry to international

\footnotetext{
${ }^{43}$ Ibid., para. 42.

${ }^{44}$ Ibid., para. 43.

${ }^{45}$ Ibid., para. 50.

${ }^{46} \mathrm{Ibid}$., paras. $57-60$.
} 
organizations meant. The Court was not persuaded by Greece's argument that the consensus procedures employed by NATO implied that no formal 'veto' could be exercised by Greece, thus relieving Greece of responsibility:

[N]othing in the text of [Article 11(1)] limits the Respondent's obligation not to object to organizations that use a voting procedure to decide on the admission of new members. There is no indication that the Parties intended to exclude from Article 11, paragraph 1, organizations like NATO that follow procedures that do not require a vote. Moreover, the question before the Court is not whether the decision taken by NATO at the Bucharest Summit with respect to the Applicant's candidacy was due exclusively, principally, or marginally to the Respondent's objection. As the Parties agree, the obligation under the first clause of Article 11, paragraph 1, is one of conduct, not of result. ${ }^{47}$

It was also accepted by Greece that the grounds for its objection lay in the difference over the name, not on other grounds. ${ }^{48}$ This was fatal to Greece's claim. Greece had indeed objected because the name dispute had not yet been resolved:

In the view of the Court, the evidence submitted to it demonstrates that through formal diplomatic correspondence and through statements of its senior officials, the Respondent made clear before, during and after the Bucharest Summit that the resolution of the difference over the name was the "decisive criterion" for the Respondent to accept the Applicant's admission to NATO. The Respondent manifested its objection to the Applicant's admission to NATO at the Bucharest Summit, citing the fact that the difference regarding the Applicant's name remained unresolved. ${ }^{49}$

Contrary to what was pleaded by Greece, such objection was not permitted under the second clause of 11(1). Greece had argued that because Makedonija would refer to itself as the 'Republic of Macedonia' rather than 'the former Yugoslav Republic of Macedonia' in NATO, the country was indeed going 'to be referred to in [NATO] differently than in paragraph 2 of United

\footnotetext{
${ }^{47}$ Ibid., para. 70.

${ }^{48}$ Ibid., para. 71.

${ }^{49} \mathrm{Ibid}$., para. 81 . See also para. 82.
} 
Nations Security Council resolution 817 (1993)'. Because of this language in the second clause of Article 11(1), Greece had no obligation not to object to Makedonija's membership of NATO. So the question before the Court was whether Makedonija's use of its constitutional name indeed triggered the exception or not. ${ }^{50}$ The Court found that the use of passive voice ('to be referred to') was relevant against Greece's construction. ${ }^{51}$ Crucially, the Court found that the Interim Accord "nowhere" required Makedonija to use "the provisional designation in its dealings with Greece" ${ }^{52}$ This had fundamental consequences-if the parties had wanted Makedonija to change its practice, they would have agreed as much:

[A]lthough the Parties were aware of the Applicant's consistent use of its constitutional name in the United Nations, the Parties drafted the second clause of Article 11, paragraph 1, without using language that calls for a change in the Applicant's conduct. ${ }^{53}$

Such an important commitment for Makedonija would not have been introduced just by implication. ${ }^{54}$ In summary, the text of Article 11(1), together with the object and purpose of the Accord, did not "permit the Respondent to object to the Applicant's admission to or membership in an organization because of the prospect that the Applicant would refer to itself in that organization using its constitutional name" ${ }^{55}$ The practice of both parties in the application of the Accord confirmed this. ${ }^{56}$

Furthermore, Greece's obligation not to object to Makedonija's membership of NATO was not qualified by Article 22 of the Interim Accord. Article 22 provided as follows:

This Interim Accord is not directed against any other State or entity and it does not infringe on the rights and duties resulting from bilateral and multilateral agreements already in force that

\footnotetext{
${ }^{50}$ Ibid., at para. 90.

${ }^{51}$ Ibid., para. 92.

${ }^{52}$ Ibid., para. 95. The Court also noted that the practice in bilateral relations was relevant: by virtue of Article 5, the Parties had found a modus vivendi whereby each would be using their preferred name in diplomatic correspondence with the other party, and affix seals with the other name on inbound correspondence.

${ }^{53}$ Ibid., para. 96.

${ }^{54}$ Ibid., para. 97.

${ }^{55} \mathrm{Ibid}$., at para. 98.

${ }^{56}$ Ibid., at para. 100.
} 
the Parties have concluded with other States or international organizations.

According to Greece, this meant that if its duty to participate in NATO decision procedures conflicted with the Accord, the NATO treaty obligation would prevail. The Court noted that even if this interpretation of Article 22 had been correct, it would still be necessary for Greece to show that it indeed had 'a duty' under the NATO treaty to object to Makedonija's membership. In the Court's opinion there was no such duty:

The Respondent offers no persuasive argument that any provision of the North Atlantic Treaty required it to object to the Applicant's membership. Instead the Respondent attempts to convert a general "right" to take a position on membership decisions into a "duty" by asserting a "duty" to exercise judgment as to membership decisions that frees the Respondent from its obligation not to object to the Applicant's admission to an organization. This argument suffers from the same deficiency as the broader interpretation of Article 22 initially advanced by the Respondent, namely, that it would erase the value of the first clause of Article 11, paragraph 1. Thus, the Court concludes that the Respondent has not demonstrated that a requirement under the North Atlantic Treaty compelled it to object to the admission of the Applicant to NATO. ${ }^{57}$

In summary, Greece had breached its obligation under Article 11 of the Interim Accord. This was, however, not the end of the matter. Could the conduct of Greece be somehow otherwise justified?

In this regard, counsel for Greece did not spare any conceivable line of defence, but, in essence, its three-pronged argument boiled down to a tu quoque. Because in its view Makedonija had also repeatedly breached the Interim Accord, Greece was entitled to invoke the exceptio non adimpleti contractus, or the rules on treaty suspension in the law of treaties, or the rules on countermeasures in the law of state responsibility. However, conscious of its arguments on jurisdiction, counsel for Greece chose not to file a counter-claim for the alleged breaches. In other words, Greece did not seek a declaration that Makedonija had breached the Accord: it only wished the Court to reject Makedonija's claim.

The Court did not find that Greece had sufficiently proven that Makedonija had been in breach of the Accord, except for one relatively minor breach

${ }^{57}$ Ibid., para. 111. 
occurred in 2004 which was, in the Court's view, entirely unrelated to the objection by Greece to Makedonija's membership of NATO. ${ }^{58}$ Even if a rule on the exceptio non adimpleti contractus existed as Greece had envisaged it, its conditions would not have been met (so the Court need not even consider if the exceptio existed or not). ${ }^{59}$ Furthermore, Makedonija's breach did not constitute a 'material' breach for the purposes of Article 60 of the Vienna Convention on the Law of Treaties, ${ }^{60}$ nor was Greece's objection to Makedonija's membership of NATO a countermeasure taken 'for the purposes of achieving a cessation' of that breach by Makedonija. ${ }^{61}$

In sum, in its dispositif the Court reached the conclusion that 'the Hellenic Republic, by objecting to the admission of the former Yugoslav Republic of Macedonia to NATO, [had] breached its obligation under Article 11, paragraph 1, of the Interim Accord of 13 September 1995. The Court refused to also declare that Greece should avoid repeating such violation in the future because its 'good faith must be presumed. ${ }^{62}$

\section{The judgment as an intervention in the name dispute}

In finding that Greece had breached Article 11(1) of the Interim Accord, the Court insisted that it did not, as such, express a view on the name dispute. ${ }^{63}$ Under Article 21(2), the Court decided it had jurisdiction over anything except choosing a name for Makedonija. ${ }^{64}$ Judge Xue and Judge ad hoc Roucounas disagreed: in their view, the Court did not have jurisdiction to hear the case inter alia because the question before the Court was inextricably connected with the

\footnotetext{
${ }^{58}$ Ibid., paras. $160-1$.

${ }^{59}$ Ibid., para. 161. In his Separate Opinion, Judge Simma filled the gap which the Court left open as to the exceptio non adimpleti contractus and clarified that, as a matter of contemporary international law, there is no space left for the concept of exceptio non adimpleti contractus beyond what has been codified in Article 60 of the Vienna Convention of the Law of Treaties (See supra, note 41). Indeed, any suggestion to the contrary would create much instability in the law and practice of international treaties, as states could unilaterally choose to forego the application of certain of their obligations in presence of non-material breaches.

${ }^{60} \mathrm{Ibid}$., para. 163.

${ }^{61}$ Ibid., para. 164.

${ }^{62} \mathrm{Ibid}$., para. 168.

${ }^{63}$ Ibid., para. 37. See also para. 130.

${ }^{64}$ Ibid.
} 
name issue. ${ }^{65}$ In this regard, the present author does not dispute that, as a matter of technical legal construction, it was perfectly reasonable for the Court to reach the conclusion it did as to jurisdiction. Incidentally, the judgment on the merits was eminently sensible: this was indeed a simple case of pacta sunt servanda, Greece having clearly breached its obligation under Article 11. However, the implications of the decision for the broader name dispute are so crucial that one wonders whether a more expansive interpretation of the exception to the Court's jurisdiction in Article 21(2) would have been warranted in view of the parties' initial wish to keep the name dispute outside the purview of the Court's jurisdiction. This is because, in order to reach its conclusion, the Court had to consider the negotiation technique employed by Makedonija-including the so called 'dual formula'-and to adjudicate, albeit incidentally, on its legality.

First, we saw that the Court found that, in the Interim Accord, Makedonija had not undertaken any obligation to call itself 'the former Yugoslav Republic of Macedonia. ${ }^{66}$ Although this is probably correct, it must be noted that this was one of the key differences between the parties and a crucial divisive element during the negotiations. Second, the Court found that Makedonija had not breached its obligation under Article 5 to negotiate in good faith with Greece. The Court first recalled its previous jurisprudence on the concept of good faith negotiations,${ }^{67}$ and then went on to consider the evidence before it, concluding that since Makedonija had in fact declared itself open also to solutions that differed from the 'dual formula, ${ }^{\prime} 8$ there was no proof that it had not negotiated in good faith so far. ${ }^{69}$

However, the Court crucially stopped short of saying that the 'dual formula' was in itself not a legitimate negotiation position under Article 5. In Judge Xue's view, the disagreement between the parties on the 'dual formula' was at the heart of the legal dispute before the parties-and it was this that put the case outside the Court's jurisdiction:

The so-called "dual formula", as revealed in the proceedings, refers to the formula whereby, ultimately, the provisional name

\footnotetext{
${ }^{65}$ See Judge Xue, Dissenting Opinion, available at <http://www.icj-cij.org/docket/files/142 /16833.pdf > [last accessed 22 April 2012], at 1-4 and Judge ad hoc Roucounas, Dissenting Opinion, available at <http://www.icj-cij.org/docket/ files/142/16835.pdf $>$ [last accessed 22 April 2012], at 6-8.

${ }^{66}$ Judgment, supra, note 5, paras. 95-7.

${ }^{67}$ Ibid., para. 132.

${ }^{68} \mathrm{Ibid}$., para. 135.

${ }^{69}$ See ibid., paras. 133-8. It is worth noting that the burden of proof of Makedonija's 'bad faith' was on Greece.
} 
will be used only between the Respondent and the Applicant, while the Applicant's constitutional name is used with all other States. Although the Court rightly concludes that, by virtue of Article 11, paragraph 1, the Applicant is not precluded from using its constitutional name when referring to itself in international organizations under resolution 817 and the Interim Accord, such a "dual formula", whose implication for the pending negotiations does not seem immaterial, was obviously not contemplated by the Parties when they concluded the Interim Accord. Furthermore, when such a formula is allegedly pursued intentionally, the matter clearly has a bearing on the final settlement of the name issue. The question in the present case, therefore, is in essence not about the Respondent's position regarding the Applicant's membership in NATO under Article 11, paragraph 1, but about the difference in the negotiation process. ${ }^{70}$

As a matter of fact, it cannot be denied that the judgment had a clear impact on the negotiating positions.

In its written pleadings, Greece had predicted that this might happen. In its arguments on jurisdiction, it declared that "a Judgment in favour of the FYROM would judicially seal a unilateral practice of imposing a disputed name and would thus run contrary to Security Council resolutions 817 (1993) and 845 (1993), requiring the Parties to reach a negotiated solution on this difference".71 And seal it it did. Indeed, the practice of calling itself'the Republic of Macedonia' has been declared lawful by the judgment, and the 'dual formula' was not explicitly deemed a breach of the obligation to negotiate in good faith. These were both clear interventions on the name dispute.

\section{On the protection of the common heritage of humanity}

In his closing oral statement before the Court, the Agent for Makedonija remarked once again why this case was important to his country. The Macedonian identity, he said, was no longer a question of choice for his people, because history had run its course:

\footnotetext{
${ }^{70}$ Judge Xue, Dissenting Opinion, supra, note 65, para. 3.

${ }^{71}$ Rejoinder of Greece, available at <http://www.icj-cij.org/docket/files/142/16360.pdf> [last accessed 22 April 2012], para. 76.
} 
Although it is not a matter before this Court for resolution, the principal difference that divides us concerns the name of my country, with all that implies to our nationality, our language and our identity. Due to the Respondent's opposition, we have suffered delays and setbacks in our quest for international recognition and legitimacy, often compromising the interests for stability in the region. Several learned counsel on behalf of the Respondent referred to the purported "choice" of our name as our crime. Yet for us, it was not a choice. Our name was the result of a long historic process; indeed, born as Macedonians, speaking the Macedonian language, it is not as if we had alternative identities to choose from. ${ }^{72}$

The response of the Agent for Greece reiterated her country's concerns for the implications of what was perceived by Greece as a cultural misappropriationonce again by reference to maps and school textbooks:

[I]n speaking of its disinterest in monopolizing the contested name, the Applicant trivializes an issue of grave and genuine concern to my country. This is an attempt to mislead the international community about the Applicant's real intentions in this regard which are far from innocent. Those real intentions can be gained from textbooks, maps, encyclopaedias, statements of its officials, all alleging historical injustice and asserting, as Greece showed in its pleadings, that the Applicant's "geographical and ethnic boundaries" extend beyond its present day borders and cover territories that are under "Greek" or "Bulgarian" "rule". This, Mr. President, is a real threat to regional peace and stability. ${ }^{73}$

Even if the Greek perspective on the history of the region were the right one, the question of Makedonija's identity cannot be brushed off as a deliberate series of scholarly mistakes by its school teachers and University professors. National identity is always socially and politically constructed-and a Macedonian state in the Balkans is nowadays an unavoidable fact, a fait accompli. In that

\footnotetext{
${ }^{72}$ Verbatim Record of Oral Proceedings, CR 2011/11, 28 March 2011 (10 am), available at $<$ http://www.icj-cij.org/docket/files/142/16386.pdf> [last accessed 22 April 2012], paras. 56-7 (emphasis added).

${ }^{73}$ Verbatim Record of Oral Proceedings, CR 2011/12, 30 March 2011 (3 pm), available at <http://www.icj-cij.org/docket/files/142/16390.pdf> [last accessed 22 April 2012], para. 14 (emphasis added).
} 
regard, although international lawyers cannot offer solutions, they can propose methods of settlement of disputes. As we saw earlier, even in the most skewed accounts there is a recognition that some heritage is in fact shared between the two countries. ${ }^{74}$ Although this may sound naïve, a medium-term objective in furtherance of the Interim Agreement may be that of fostering academic and cultural dialogue across the borders of the two countries-perhaps starting precisely from a joint study of this shared heritage. As the general principles on the protection of cultural property show, and as UNESCO constantly advises, certain elements of world culture (such as Alexander the Great's empire and the literature that came therewith) are the common heritage of the whole of humanity, not of a specific country. ${ }^{75}$ It is the responsibility of Makedonija and Greece to find an intelligible way to share and preserve their collective heritage rather than attempt to litigate it before international courts.

The Court concluded its reasoning by "emphasiz[ing] that the 1995 Interim Accord places the Parties under a duty to negotiate in good faith under the auspices of the Secretary-General of the United Nations pursuant to the pertinent Security Council resolutions with a view to reaching agreement on the difference described in those resolutions" ${ }^{76}$ The collective future of Makedonija and Greece is as partners in the European Union and NATO, not as opposing sides in a never-ending conflict over Makedonija's name. While there is no denial that this a serious dispute over matters which touch upon the identity of both countries, it is equally obvious that these are no longer times for such disagreements. In times when the principle of self-determination of peoples has become a peremptory norm of international law, and foreign domination through colonization is no longer acceptable let alone something to be proud of, one wonders whether the 'real' heritage of past historical pan-Asian conquests is a legitimate point of international dispute. As Scipio Aemilianus allegedly acknowledged just after having destroyed Carthage on behalf of Rome, human glory is forever ephemeral. ${ }^{77}$ Whomever Alexander the Great 'belongs' to, at some point his empire fell, as all empires (and their subsequent shadows)

\footnotetext{
${ }^{74}$ Supra, note 8 and accompanying text.

${ }^{75}$ See Article 6(1), Convention concerning the Protection of the World Cultural and Natural Heritage 1972, 1037 UNTS 151 (both Makedonija and Greece are parties thereto); see also Convention for the Safeguarding of the Intangible Cultural Heritage 2003, available at <http:// unesdoc.unesco.org/images/0018/001897/189761e.pdf> [last accessed 22 April 2012].

${ }^{76}$ Judgment, supra, note 5, para. 166.

${ }^{77}$ Polybius (208-118 BCE) tells us of the tears shed by the Roman general after having accomplished the destruction of Carthage in 146 BCE: Histories, XXXVIII, 22, English translation at <http://penelope.uchicago.edu/Thayer/E/Roman/Texts/Polybius/38*.html> [last accessed 22 April 2012].
} 
are thankfully bound to do. 